\title{
The Impact of Bridging Whole-Student Understanding Between Elementary Students and Preservice Teachers
}

\author{
Dr. Nissa Ingraham \\ Dr. Susanne Nuttall \\ Northwest Missouri State University
}

doi: 10.19044/ejes.v4no3a1 URL:http://dx.doi.org/10.19044/ejes.v4no3a1

\begin{abstract}
This qualitative study reviewed the preparedness of preservice teachers to meet the needs of struggling readers in an urban Florida school. The research was guided by the overarching question: What is the impact of targeted diversity training on rural university preservice teachers when creating performance-based tasks (PBTs) for urban-core elementary lowperforming students? The research reviewed the impacts of specific diversity training of preservice teachers on quality construction of a PBT intended to meet the needs of diverse, urban-core, and academically struggling elementary students. Data triangulation was employed by reviewing researcher field notes during the targeted-diversity training sessions, a student pre- and posttreatment survey, and archived communication with the program's philanthropic liaison. Data were analyzed using open coding to allow themes to emerge. Key findings indicated common impacts through the lenses of logistics, collaboration, and reality. Implications speak to preservice teachers, educational partnering, and future teacher employment.
\end{abstract}

Keywords: Preservice teachers, whole child, diversity and literacy.

\section{Background}

As state and national teacher-preparation accrediting agencies are undergoing transformation, literacy-instruction preparation is imperative to developing an elementary teacher (Cuthrell et al., 2014). Although the curricular areas of mathematics, science, and literacy are all taught in an elementary teacher-preparation programs, literacy instruction requires greater credit hours to be fulfilled (Department of Elementary and Secondary Education [DESE], 2016). As Stevens-Smith, Warner, and Padilla (2014) noted, "A strong foundation in literacy underpins success in every discipline" 
(p. 109). This quotation illustrates the notion of the importance of preparing elementary teachers to be quality literacy-learning facilitators.

Although literacy-instruction preparation mandates inclusion of the subcategories of remediation, assessment, and pedagogy, a disconnection persists between these notions and what Maslow (Karodia, Soni, \& Soni, 2016) recognized and what Noguera, Darling-Hammond, \& Friedlaender (2015) reported to be crucial for all teachers to understand: "the context of education, both inside and outside of school" (p.2). Although the foundational understanding of how to teach a student to decode words and how to become a fluent reader are important, if the student is coming into the classroom afraid or does not believe their race is valued, the reading lesson the teacher has planned will likely not impact the student.

Understanding the "whole child" or the various life experiences the child brings to the classroom is extremely important to meeting the child's primary needs (Suarez-Orozco, Suarez-Orozco, \& Sattin-Bajaj, 2010). These are not new ideas, as illustrated by Maslow's hierarchy of needs research performed in the 1950s; however, it remains to be an area underemphasized in teacher-preparation mandates (McLeod, 2014). Without a teacher fully realizing the needs a child brings with them to the classroom, any other instructional efforts can be hollow. For example, if a child comes into the class feeling hungry, no matter how entertaining a teacher is during class, the child may not be able to focus on the instruction taking place. Another example is if a child comes to a school where his own cultural background is inapparent or not vital, this student may feel hesitant to fully interact in the classroom. If a student comes to school feeling uncertain, afraid, or distracted, and the teacher is not cognizant of these issues and how they can impact the student's learning, the teacher is not meeting the student's needs to develop scholastically (Ellis, 2008; Jensen, 2009; Payne, 2002), which can negatively impact the student, preventing the student from developing academically to full potential, and can negatively impact the teacher's ability to retain the job or desire to stay in the profession (DESE, 2015; Johnson, Berg, \& Donaldson, 2005; Scott, 2008). For this reason, further investigation of the impacts of direct diversity training on preservice teachers is needed. Such investigation would further inform teacher-preparation institutions and elementary school administration about the merits of direct diversity instruction on the development of teacher's understanding of how to meet diverse students' needs through the tasks they develop.

Students who are low performing in the areas of mathematics and language arts at Acme Elementary School in Urban Center County, FL, were invited to enroll in the Ambition Academy. The Ambition Academy is an after-school institution in the school building, aiming to help meet the scholastic, emotional, and social needs of low-performing students who attend 
the school. The endeavor is supported by a philanthropic group in Urban Center County, who requested assistance from Rural University elementary education majors to help build a curriculum to help meet the three areas of need of Ambition Academy. As this endeavor was new to the district and to the university, research on the impact of the project on the elementary students and Rural University undergraduate education majors was measured through qualitative measures to answer the overarching question: What is the impact of targeted diversity training on rural university preservice teachers when creating performance-based tasks for urban-core elementary low-performing students?

\section{Key Terms}

The following concepts can have varying meanings; to hold constant the intended meanings, we define these concepts as they pertain to this research.

\section{After-school programs.}

Acme Elementary School created an after-school program to which students were recruited based on reading levels, home life, and propensity for drop-out. A decade of research and evaluation studies, as well as large-scale, rigorously conducted syntheses across many research and evaluation studies, confirmed that children and youth who participate in after-school programs can reap a host of positive benefits in a number of interrelated outcome areas: academic, social/emotional, prevention, and health and wellness (Little, Wimer, \& Weiss, 2008) Programs with a strong intentional focus on improving social and personal skills have been found to improve students' self-esteem and self-confidence (Durlak \& Weissberg, 2007). Research and evaluation studies have shown that participation in afterschool programs have a positive impact on juvenile crime and help reduce pregnancies, teen sex, and boys' marijuana use (Goldschmidt, Huang, \& Chinen, 2007; Philliber, Kaye, \& Herrling, 2001; Philliber, Kaye, Herrling, \& West, 2002).

\section{Performance-based task.}

In the act of learning, people obtain content knowledge, acquire skills, develop work habits, and practice the application of all three to real-world situations. Performance-based learning and assessment represent a set of strategies for the acquisition and application of knowledge, skills, and work habits through the performance of tasks that are meaningful and engaging to students (Educators in Connecticut's Pomperaug Regional School District 15, 1996). Preservice teachers create PBTs for after-school programs based on student reading levels, book choices, and interest inventories. Preservice teachers are assigned a student with the book selection and proceeded to create 
engaging tasks aligned with standards. These tasks are typically open-ended, establish novel and authentic contexts for performance, and integrate two or more content areas as well as 21st-century skills (Defined Learning, 2015). Because these PBTs are open-ended, preservice teachers create criteria and scoring rubrics for evaluation. Performance tasks yield a tangible product or performance that serves as evidence of learning (Defined Learning, 2015.) Through this process, assignments become more authentic and more meaningful to students.

\section{Preservice teachers.}

Preservice teaching is a period of guided and supervised learning and teaching. The university preservice teacher is gradually introduced to the teaching role for a particular class by a mentor or cooperating teacher. The preservice teacher begins as an observer and finishes the preservice-teaching experience as a competent professional (Virginia Wesleyan College, 2017). Guess-Newsome \& Lederman (1991) found that preservice teachers are positively influenced by opportunities to think about teaching subject matter.

\section{The Project Design}

This qualitative research was a bounded case study examining pre- and postdiversity surveys and researcher field notes, and reviewing archived communication with the philanthropic-program liaison. Additionally, the research incorporated general observations of the school and university, and included an analysis of historical documents and artifacts related to the school and university programs. This triangulation of data provided trustworthiness to the study (Merriam, 1998).

\section{Participants}

The rural university preservice teachers involved in this study were teacher-preparation candidates who were at the midpoint preparation level or beyond in their elementary education studies. Students became participants voluntarily, not through a course. They chose to be a part of this voluntary diversity training and performance-based-task creation team to receive diversity credit and to positively impact urban elementary students.

The third- through fifth-grade elementary students involved in this study were in an urban district and were all selected to be in the academic assistance, afterschool program, Ambition Academy. Students were selected due to their low state standardized test scores, their potential for drop-out, and their high socioeconomic needs. The Ambition Academy is a highly selective program, wherein someone has seen that included students could be impacted by additional time with mentors and additional curriculum review 


\section{Implementation Process}

These rural university preservice-teacher candidates had the opportunity to meet outside of class time to develop PBTs based on academically rewarding texts used by the elementary Academy. The preservice-teacher candidates met with two faculty members and received a targeted-diversity awareness-training protocol, ending in the development of the PBT. The process took approximately 5 hours to complete by each student. Once PBTs were completed, faculty members sent the PBTs to the Ambition Academy coordinator for implementation in the elementary after-school Academy program.

The targeted-diversity training involved five areas of study by preservice teachers. Preservice teachers maneuvered through the five areas of diversity training, led by a professor through each station. The first station of study was reviewing the elementary students for whom they would be writing the PBTs. This was achieved by first watching a 5-minute video the school had made about the Academy, including direct testimonials by students in the program. Students discussed their aspirations for the future and how the Academy has impacted their lives. Some students mentioned their home situations and how being part of the Academy helped them in that way as well. Next, preservice teachers reviewed Academy students' demographic information and aggregated state standardized-test information. A professor led a discussion about the data and how it could impact PBT construction. The next station was a review of research on poverty and racial diversity. Preservice teachers read excerpts from Payne (2002) and Jensen (2009) prepared by the faculty. A professor embarked on a discussion with the preservice teachers about of how this knowledge about the intersection of poverty and education could help preservice teachers refine their targeted growth of Academy students while helping preservice teachers better select appropriate literature that would enhance students' understanding of the world, but not hinder their cultural development as an urban-core student. The literature selection was the fourth station in the targeted training. As the final training station, students began developing their version of a PBT with the continued support of the professors.

\section{Research Findings}

Using various tools, data accrued. One data-collection tool was a survey completed by preservice teachers prior to completion of the diversity training and the same survey completed after diversity training, including the creation of the PBT. Researchers made field notes while working with preservice teachers on the project, including gathering direct quotations from preservice teachers during the diversity-training experience. Additionally, e-mails were reviewed from a philanthropic after-school-program liaison who 
was working with the school's afterschool program. Also, historical data were reviewed from the school's and state education department's websites.

In relation to the overarching question guiding this research-What is the impact of targeted diversity training on rural university preservice teachers when creating PBTs for urban-core elementary low-performing studentsresearch showed increased growth in teacher preparedness following targeted diversity training. The areas most impactful were (a) logistics involving time consumption, availability of resources, and space used; (b) collaboration between school officials and preservice teachers, teacher-to-teacher collaboration availability, and teacher-to-student interaction; and (c) reality and the understanding of the reality of the life the students lives, the reality of the impact a teacher can have on a student and the student's future, and viceversa: the impact a student can have on a teacher's future.

\section{Logistics}

Although many preservice teachers did not reference logistics, it was seen in field notes and e-mail trails. As the development of the PBTs began, preservice teachers were allowed to use any book they chose and thought was a rich authentic text for students to read. However, when those initial PBTs were given to the school, not all books were available to students through the school library. This made follow-through on PBT difficult. After reflection, the researchers procured electronic listings of books available at the local library, and began having the preservice teachers only write PBTs for those texts.

Another logistical issue, noted by the researchers in the field notes and e-mail trails, was the physical set-up of the room where preservice teachers met to develop the PBT. At the beginning of the study, the researchers planned to conduct instruction of diversity issues and issues facing students at the Academy (racial diversity, socioeconomic diversity, and linguistic diversity); however, it quickly became apparent that the project would not work effectively within those structural constraints. Preservice teachers, much like full-time teachers, do not have the luxury of dedicating a large chunk of time to an effort on one day. Instead, they needed to develop a system in which preservice teachers could move from station to station, learning about the students for whom they would be writing the PBT. The stations were a video of students and the Academy, information about poverty (following Payne's notions, Jensen's concepts, and ethnic implications for literacy selection), and state standards needing to be fulfilled. With these three concepts, students were able to see the whole child, the needs they had to meet and the curriculum in which students need instruction.

As all preservice teachers were mandated to work on most development in the room, the researchers found this led to great opportunities 
for preservice teachers to ask questions about cultural issues surrounding the Academy students. Also, this structure of workspace created greater collaboration among preservice teachers, with one preservice teacher noting how "nice it was to be able to work in the room together to bounce ideas off of each other." Another commented it was nice to be working together in a more cohesive "team planning," similar to what they assumed it would be like if they worked in a larger district where they would have to perform similar functions.

\section{Collaboration}

In the study, researchers referenced various types of collaboration that occurred, with teacher candidates commenting on the benefit of collaborating with the Academy and the researchers noting collaboration as teacher candidates developed their PBTs in the classroom. Preservice teachers were able to work together in the same space, affording them the opportunity to collaborate, which left them feeling that the product they were developing was richer and would have a more effective impact on students' development toward meeting state standards.

Additionally, the researchers noted the collaboration that was able to naturally emerge between the researchers and preservice teachers. Preservice teachers asked rich questions about students' ethnicity, language ability, and socioeconomic status and how it would impact students' ability to successfully complete a task. One issues discussed was the school's inability to purchase new books. Also, preservice teachers had not considered that parents would not be able to purchase books. Many epiphanies emerged when the discussion centered on parents having to decide between purchasing food or a book for their child. This was compounded by the notion that preservice teachers had seen children's faces and knew who were going to be the children completing the tasks. In effect, seeing their faces created a quasicollaboration between the preservice teacher and the students.

\section{Reality}

One area highlighted by many participants was the reality illuminated through working with real students who have real lives that the college students' work would impact. This comingled many times with the notion of collaboration; that collaboration allowed for or afforded a real-life feel to the development of the PBT. Originally, many preservice teachers identified interest in the experience because of the diversity hours they would gain toward graduation. However, as program construction progressed, the more preservice teachers made comments such as, I "didn't care about the diversity hours. [I] was excited to help the kids in the school." Another student commented, "[I liked] knowing that [I was] helping the kids and to see the 
kids on the video." The same student said that it made "[I] look at the PBT differently, because it was real now."

During the training sessions, including the creation of the PBTs, the two faculty members kept field notes, including comments they heard students make during the training, and comments students made to them directly. Some made directly to the faculty routinely heard were that preservice teachers "liked it because it was for real kids." One participant, after watching the video of students who would be doing their PBT, said "[I would] like to go to Florida" with the faculty to meet the students in person. Another student indicating liking to watch the video of the students and "knowing that those are the kids that will do the PBT - it is nice to help them out."

Students completed surveys prior to undergoing the diversity-training experience, including the creation of the PBT. After students completed the work on the diversity experience, they completed a postexperience survey. Of the students who responded to the postdiversity-training survey, $100 \%$ responded to the open-ended question saying they felt the diversity-training experience had helped them better understand how to work with their future diverse population of students; $80 \%$ of students responded to the Likert-type scale that they believed they were at the same level of preparedness to work with diverse students, whereas $20 \%$ responded that they believed their preparedness had increased.

\section{Making Meaning}

Milk and cookies go together. This mixture results in an integrated sensory experience that brings forth a great pairing, a mixture blending with a feel good experience. The combinations of two entities (Rural University, Ambition Academy) in our research project resulted in these three attributes of the unification:

\section{Perfect Pairings}

Just as milk and cookies equal the perfect pairing, preservice teachers and elementary students fused. Preservice teachers at Rural University are in a predominately rural, Caucasian environment. As a result of this geographic and ethnic isolation, experiences with heterogeneous populations are minimal. Of elementary students at Ambition Academy, 99\% receive free or reducedprice meals and are predominately African American with minimal contact with Caucasian environments. These students are geographically isolated as a result of their socioeconomic status. This merger also coupled a higher institution of learning with a public school. The talls (preservice teachers) were matched with smalls (elementary students, Grades 3-5) for relevant and authentic planning in literacy. Additionally, preservice teachers unified with Ambition Academy to access available literature and other school supplies 
necessary to complete tasks. Talls even conducted a supply drive to ensure smalls would have the adequate materials to accentuate the PBTs.

\section{Mixture Blending}

Just as milk and cookies mix to form a unique and desirable blend, preservice teachers were assigned PBTs to create for the smalls at Ambition Academy. This merger began with understanding of instruction and interests of partners at the elementary school. The consolidated vision became clear and meaningful when creations of PBTs were in the hands of smalls at Ambition Academy. Rather than an assignment to be turned in for a grade, the genuine relevance was an epiphany because this project became an endeavor of love and labor that was to be placed in the hands of the smalls.

\section{Feel Good}

Just as milk and cookies cause a release of chemicals for a prodigious sensation, the same feeling was internalized as this project unfolded. Skyping with the director of Ambition Academy and viewing several demonstration videos resulted in personalized, precious, and picture-perfect participation. Likert results were received from smalls upon completion of the PBTs. Preservice teachers soundly affirmed their excitement to help these learners with a real-world experience.

\section{Conclusion}

Diversity training for preservice teachers is a prominent topic in teacher preparation programs (Council for the Accreditation of Educator Preparation, 2015). Review of possible curricular impacts on preservice teachers' awareness and on the future students of preservice teachers needs to be conducted (LeMaistre \& Pare, 2010). As educators move into this latest era of teacher training, they owe it to future generations to heed the research and tackle the research still needed to better understand how teacher-preparation training, particular to diversity, impacts the preservice teacher, the $\mathrm{K}-12$ student, and the teaching profession as a whole (Johnson et al., 2005). Payne (2002) and Jensen (2009) each provided a wealth of research about the impacts of poverty on the whole child. However, with a more discrete review of the impacts on specific curriculum provided in teacher-preparation programs, and if relationships exist between preparation programs and $\mathrm{K}-12$ systems to use university-prepared curricula, more understanding can be forged. Through understanding, change in the curriculum and impacts to $\mathrm{K}-12$ can occur.

\section{Preservice Teachers}

As preservice teachers experienced the creation of authentic lesson planning, they more highly valued commitment to the plan. As preservice 
teachers made a connection, face to face, with a struggling learner, the obligation to individualize instruction manifested. As preservice teachers reviewed the students, their demographic information, and their living situation, and researched poverty prior to building curriculum pieces, the quality of the plan improved. As preservice teachers discovered the dichotomy of poverty in a school setting, empathy and passion toward the circumstance heightened.

\section{Educational Partnering}

Partnering with a $\mathrm{K}-12$ school early in coursework increased awareness of the institutional setting for the preservice teacher. Collaboration between the administration and the preservice teacher fostered collegialism and rendered posing and pressing questions regarding the profession and the needs of the whole child. As students completed the lesson plans created by preservice teachers, students and classroom teachers provided feedback and reflection.

\section{Future Teaching Employment}

Preservice teachers will be competing for employment. Those who can prove knowledge gained from veritable and genuine opportunities that work directly with children, rather than about children, will be better prepared in their future classrooms. Additionally, those preservice teachers who exude passion and joy and realize the importance of meeting individual needs will be at the top of the list for hiring.

\section{References}

Council for the Accreditation of Educator Preparation. (2015). CAEP accreditation standards. Retrieved from http://caepnet.org/standards/introduction

Cuthrell, K., Stapleton, J. N., Bullock, A. A., Lys, D. B., Smith, J. J., \& Fogarty, E. (2014). Mapping the journal of reform and assessment for an elementary education teacher preparation program. Journal of Curriculum and Instruction, 8, 67-85. doi:10.3776/joci.2014.v8n1p67-85

Defined Learning. (2015). Performance task PD with Jay McTighe. Retrieved from https://blog.performancetask.com/

Department of Elementary and Secondary Education. (2015). Recruitment and retention of teachers in Missouri public schools. Retrieved from https://dese.mo.gov/sites/default/files/2015-RRReport.pdf

Department of Elementary and Secondary Education. (2016). Elementary education English/language arts competencies. Retrieved from https://dese.mo.gov/sites/default/files/elem_englarts.pdf 
Durlak, J. A., \& Weissberg, R. P. (2007). the impact of after-school programs that promote personal and social skills. Chicago, IL: Collaborative for Academic, Social, and Emotional Learning.

Educators in Connecticut's Pomperaug Regional School District 15. (1996). A teacher's guide to performance-based learning and assessment. Alexandria, VA: Association for Supervision \& Curriculum Development.

Ellis, R. (2008) Understating second language acquisition. London, England: Oxford University Press.

Goldschmidt, P., Huang, D., \& Chinen, M. (2007). The long-term effects of after-school programming on educational adjustment and juvenile crime: A study of the LA's BEST after-school program. Los Angeles, CA: University of California, Los Angeles/CRESST. Retrieved from http://www.lasbest.org/resourcecenter/LASBEST_DOJ_Study_Brief.pdf Guess-Newsome, J., \& Lederman, N. G. (1991, April). Preservice biology teachers' subject matter structures and their relationship to the act of teaching. Paper presented at the Annual Meeting of the National Association for Research in Science Teaching, Lake Geneva, WI.

Jensen, E. (2009). Teaching with poverty in mind: What being poor does to kids' brains and what schools can do about it. Alexandria, VA: ASCD.

Johnson, S. M., Berg, J. H., \& Donaldson, M. L. (2005). Who stays in teaching and why: A review of the literature on teacher retention. Boston, MA: Harvard University.

Karodia, A. M., Soni, D., \& Soni, P. (2016). Wither higher education in the context of the fees must fall campaign in South Africa. Research Journal of Education, 2(5), 76-89.

Little, P. M. D., Wimer, C., \& Weiss, H. B. (2008). After school programs in the 21st century: Their potential and what it takes to achieve it. (Issues and Opportunities in Out-of-School Time Evaluation Brief No. 10). Cambridge, MA: Harvard Family Research Project.

McLeod, S. (2014). Maslow's hierarchy of needs. Retrieved from http://www.simplypsychology.org/maslow.html

Merriam, S. B. (1998). Qualitative research and case study applications in education. San Francisco, CA: Jossey-Bass.

Noguera, P., Darling-Hammond, L., \& Friedlaender, D. (2015). Equal opportunity for deeper learning. Retrieved from http://www.jff.org/sites/default/files/publications/materials/Equal-

Opportunity-for-Deeper-Learning-100115a.pdf

Payne, R. (2002). Understanding learning: The how, the why, the what. Highlands, TX: Aha Process. 
Philliber, S., Kaye, J. W., \& Herrling, S. (2001, May). The national evaluation of the Children's Aid Society Carrera-Model Program to prevent teen pregnancy. Accord, NY: Philliber Research Associates. Retrieved from http://www.childrensaidsociety.org/media/general/cas-

Teen_Pregnancy_Prevention.pdf

Philliber, S., Kaye, J. W., Herrling, S., \& West, E. (2002). Preventing pregnancy and improving health care access among teenagers: An evaluation of the Children's Aid Society-Carrera Model. Perspectives on Sexual and Reproductive Health, 34(5), 244-251. Retrieved from http://www.agiusa.org/pubs/journals/3424402.pdf

Scott, D. G. (2008). Retention of early career teachers engaged in Missouri's career education mentoring program (Doctoral dissertation). University of Missouri, Columbia.

Stevens-Smith, D., Warner, M., \& Padilla, M. (2014). The changing face of public education: The process of "revisioning" elementary teacher preparation programs. Journal of Cultural Diversity, 21(3), 108-111.

Suarez-Orozco, M., Suarez-Orozco, C., \& Sattin-Bajaj, C. (2010). Making migration work. Peabody Journal of Education, 85, 535-551. doi:10.1080/0161956X.2010.518053

Virginia Wesleyan College. (2017). Preservice teaching. Retrieved from https://www.vwc.edu/academics/majors/education/fieldexperiences/preservice-teaching.php. 